( 813$)$

實 遊 虫

離三余

得 機 就 一

夕 轉 天 太

捧論 正

$\exists=$ 述

以 其 哖

三幼次兵

第 之虫 天゙ 公

第此生正行

一處物分東

章 $=$ 學 年 京

記 的十醫

述性筫事

並本虫關公誌

二被研 $九$ 中

其包究研關旮

蟹需補究學號

奻遺 $\exists$ 會 及

二幼卜報 硁 ビ

寄虫篇告誌

生 $テ$ ン 节四分

七宿占而志路

ル七

數 $儿$ 其於於

解 後 天

蟹本本余

ノ虫被發

地關 露 筧

理 站牦

的實䖮保

分殓㙰

布䊽宿中

區續主 間

表第第第第第緒

要章章章罩章章章言

緒惹本本查本本本本

緒編虫虫染被被

八元入r虫包包

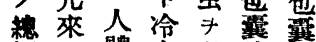

括了體血以幼幼

言

終奇働 品峦

蕧生物動步宿

徸吸特物产售

就虫蛙食動

$\bar{\tau}$ 及試物

十魚驗誐地

慗就驗理

目

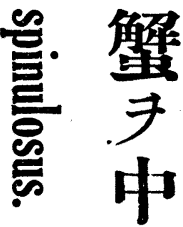

間

= 伯

次

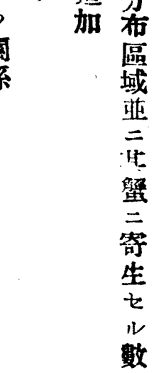

專

京

布

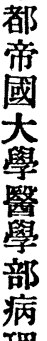

단

N

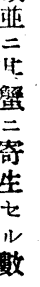

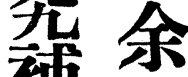

迎

シ 消 宿

更华主

三管

三㐫学

新尔新

事

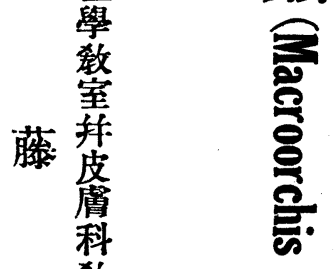

亮

述 

二佾 ナ八附 ル口記 $\Rightarrow$ 吸 常 盤可 支 $\neq$

刺 其

欶 後

著 蟹

章

明 檢

ナ 索

リ $=$

口 $\exists$

本奛

被 少本

句直被

整

幼

虫

于

以

テ

ノ

動

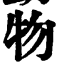

試

驗

ノ

追

加

节七

有

七其

此 㣳

墨 楀

卜テㅇ四テ本名搰倘

多個正, 年第芮文東以次

, 可

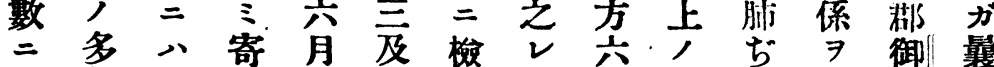

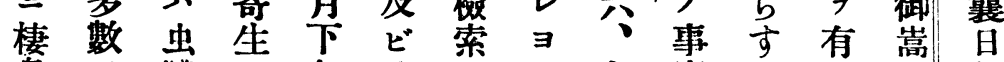

息 $\exists$ 體 $\exists$ 旬第七步七實さ 七町初

ス算人證捕四り東肞八まザ, メ

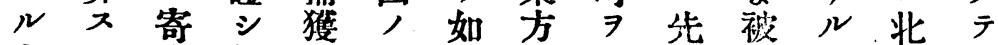

上ル生得七流斯四距年佨所部罫

流 = 陰ザル 行 =、テ既 囊ナ二蟹

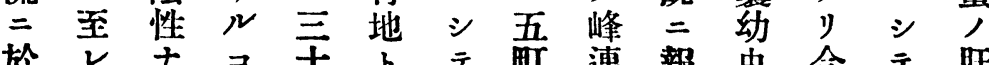

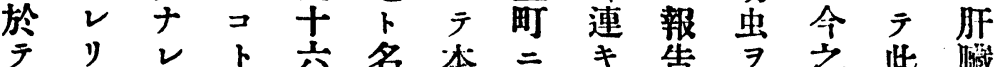

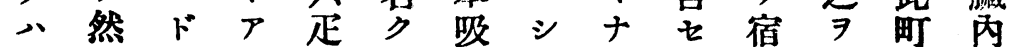

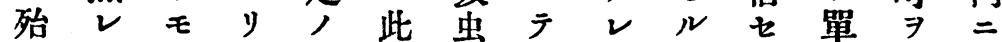

ド 他 即蟹 第 $八 上 ト ゙$ 所ル二圍 本

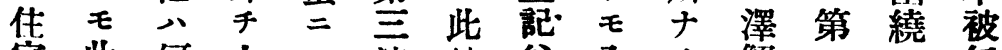

家此何大八流. 地谷全り蟹一七包

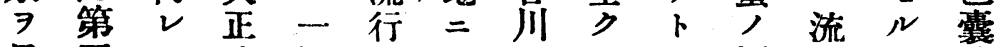

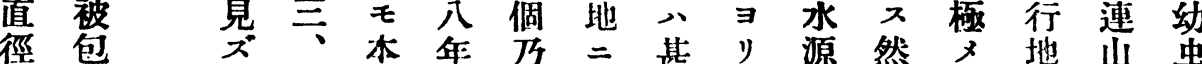

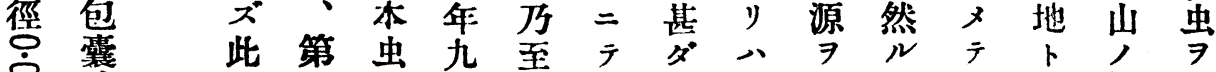

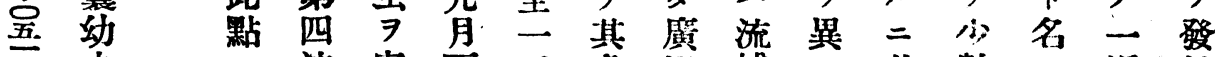

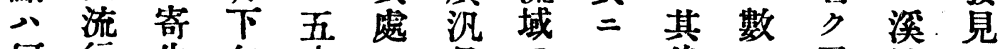

何行生向六=且 7 後 $=$ 又流

刺極 等 地 $シ$ 個 任濃巽 ル本

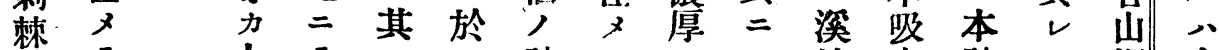

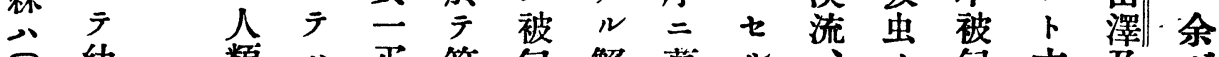

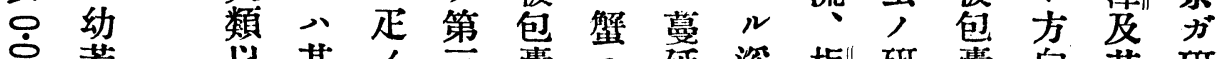

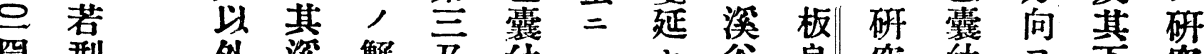

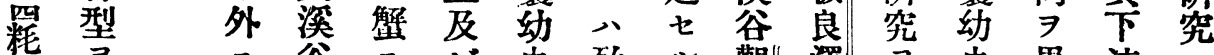

$\exists \quad$ 谷 $三$ 虫殆 $上$ 觀 澤 $\Rightarrow$ 虫異流二

長检本人寄第 $\rightrightarrows$ モ 音卜進

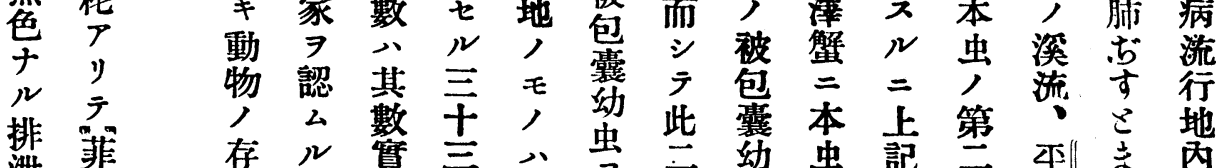

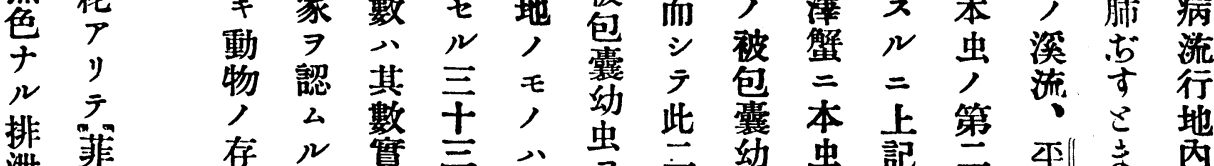

渄菲 存

马蟹三人少檢行 $\exists$ 檢一行澤卜

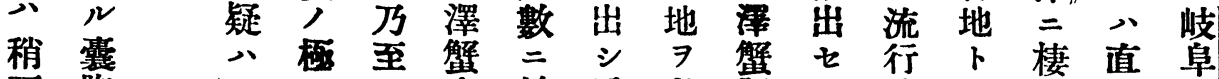

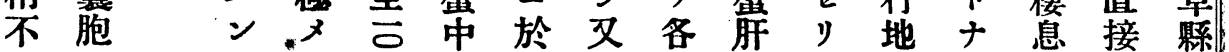




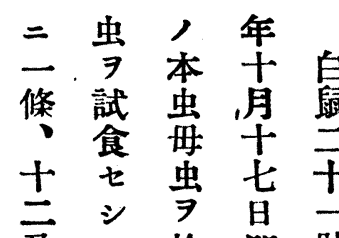

永丈 檢 即 號

人 ル 出 チ

厂 モ 得 食 正

所, 夕後公

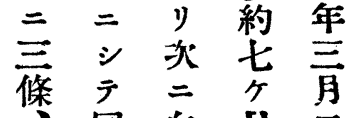

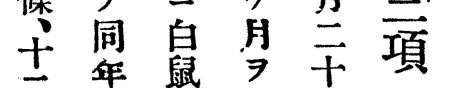

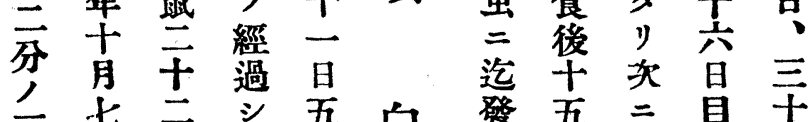

三 七 豆 部五

所即 $心$ 檢 個 鼠章旦南京相個

二 所大不年

二試正点同用

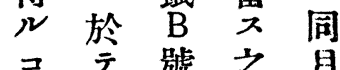

同

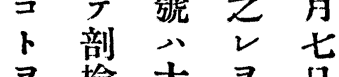

$\Rightarrow$ 檢大 7 日

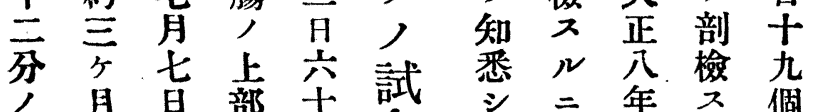

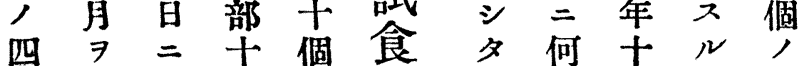

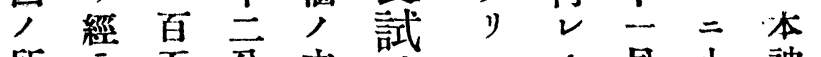

所 五胥 本 驗

三之支, 被

條剖、, 亮

以. 检 同 所幼

上 月 二 虫

含 計 三音

八小 公食

條䑄二七七

人六十

母上十 $上$ ×

虫部五㸷名

㭘士個人地モ

出页本叫元

シ人被所二

得一包二シ

タノ囊 言 テ

リ所幼佟同
用小被

部七腸包

二日 上䤖

テ九十虫

モ 個 三

虫厂分試

體本, 食

被一七

認包ノシ シ

囊 所

品 約

由 虫自 背

是誰試集モ

之食十二

本七 三

虫 $シ$ 尔 テ

八メノ同

南夕。月
殊 ズ 食大試

二本後大食余

家實八 正 七

鴨驗日十 シ 既

ガ 目年泥

本據二六名大

虫 乙 月 ル 正

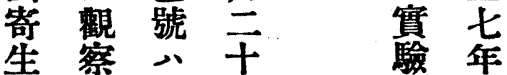

二 翌八成度

留 ル 月 日 維 二

第 與 斯

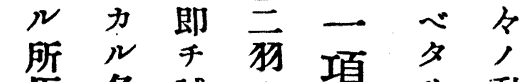

榀多試ノ具り動

丈 數 食家 而物

テノ後 鴨

南少被十二家文主

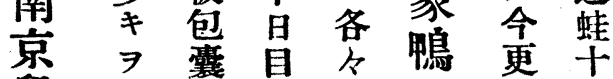

鼠知动撲 管 $于$ 二頭

于 次虫媇百用次

家检十七 列鼠

鴨 シ 倜 テ 寒 十

二小宛

試腹ノ言式

食沯小言式 如

七細型食多

シ檢被試種る

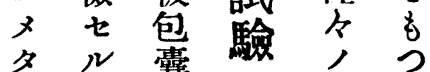

$N=$ 动動

二们 中

拘 $レ \frac{7}{7}$

八 二. 試

ラ於 食

ス テ セ

虫モ シ

體—メ

习條甲

檢ノ號

出虫

得 7 月

ザ 認 五

ル $厶$ 日

小 即

物 文

烏 7 白

類 得 試
就

テ 小

試猫

驗 三

行 二

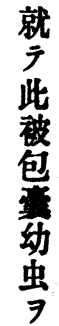




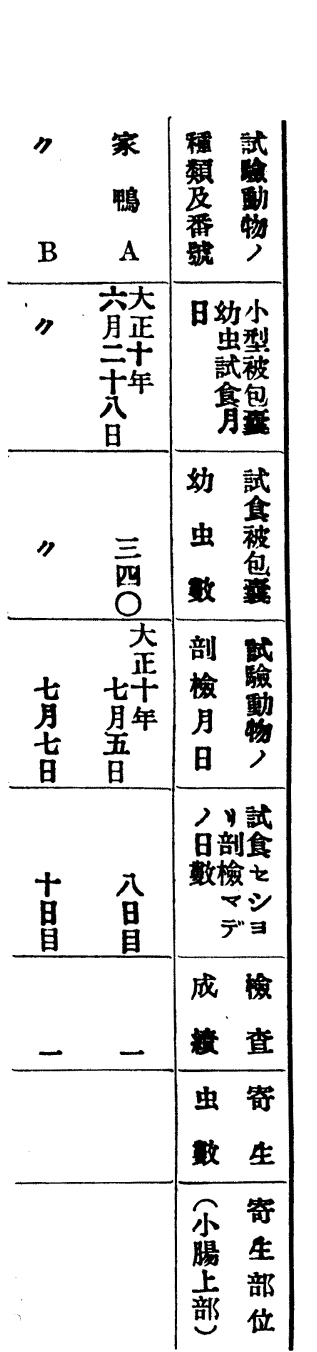

回

或含 䍃 $\mathrm{A}$

其 記

第 成

壹綪

被寄,

包生 動

囊

孧吸試

$\exists$ 虫 $\exists$

以, 總

天 整 括

動 基

物 寄 動

試 生 物

驗 部

績 等 類

表 番

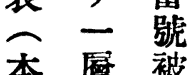

本曆被

度 瞭筁

于 幼

浮,

台試

可食

表毄

素

ス 試

$\therefore$ 七

次

, $x$

恕名

月

動

物

剖

整

七 检 四

項

示

以 得

, 步被

試 部

缩焂 夕

括

本

虫,

卌

虫

虰

检 翌

出 年

得

告

昆

即

試

食

後
目鬼士

$=\mathrm{B}$ 三家

相 號 旦

富学自

亏 正 相

之十當大

年

7 兵 $\overline{1}$

剖目剖年

检辛检公

第 剖立

\section{ス 兵}

旦項

上本犬

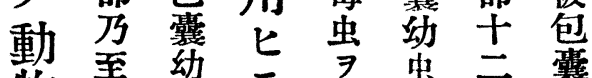

物至苭 示虫蚠露

膓試, 出

驗於食食試部

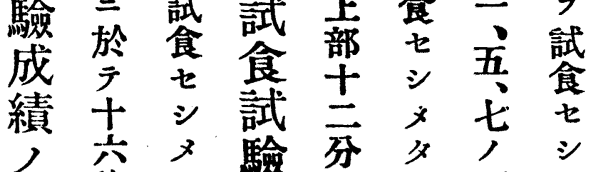

試

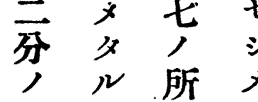

三, 於

所 = 毛

於紊各

䛷前苑

メ 三合 翌

夕干計青

y旦至

即 條 干

千 7 -

試 檢 日

食 出 即

後 Ł車

翌次試

立家墕
三翌條
後学

月

年,

覀

テ 號

剖

检大

入

2 七

第 二 年第

五尔四

腸 色 項

卡宣

家士南 モ

兔分本儿 用一被正

と包

七所囊卜

二出

試蓧試用

食本食七

試虫

騟

虫夕試

認儿食

邓試

y $=$

驗

i

于

年

年

月

兵

日

即

于

試

食 


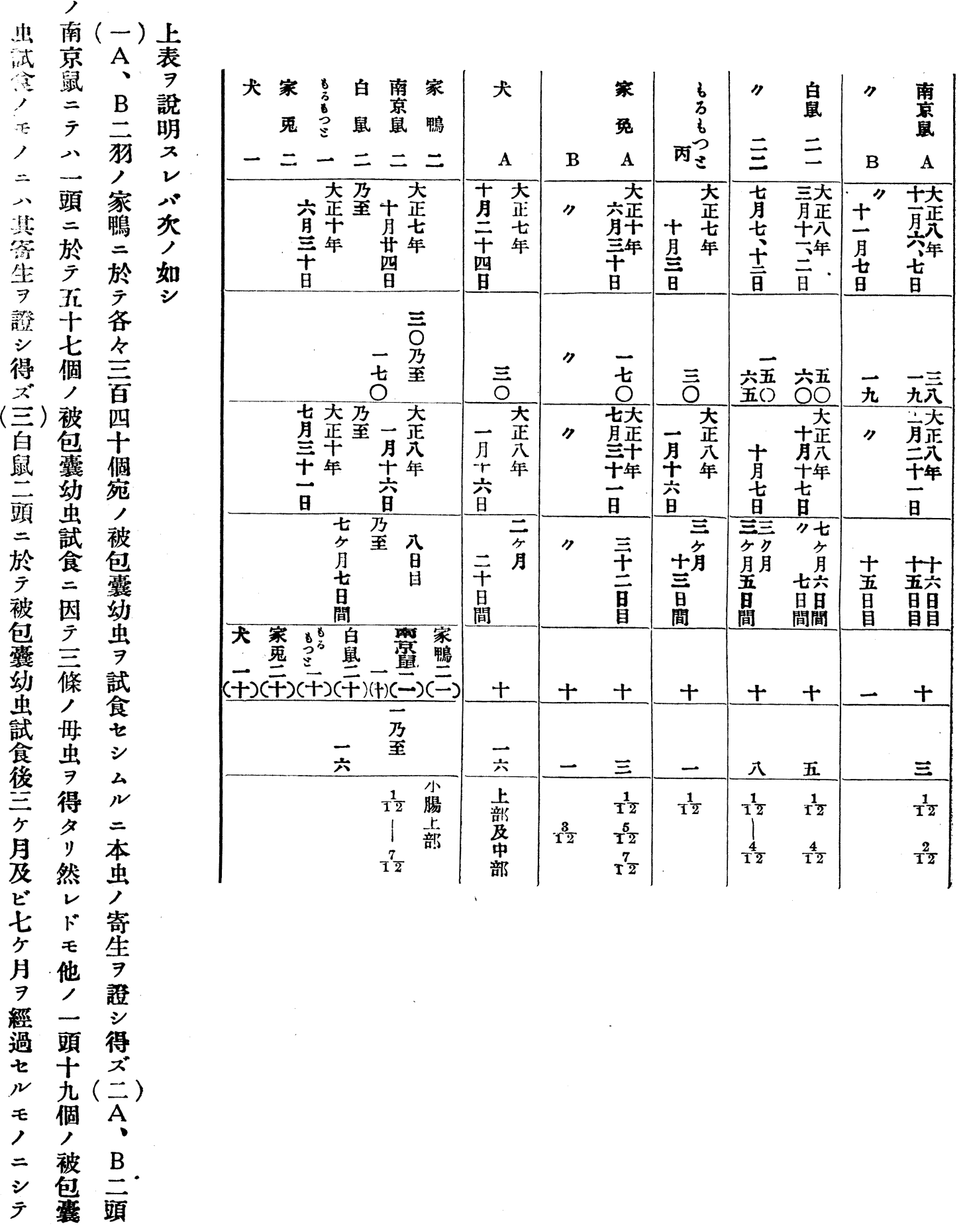




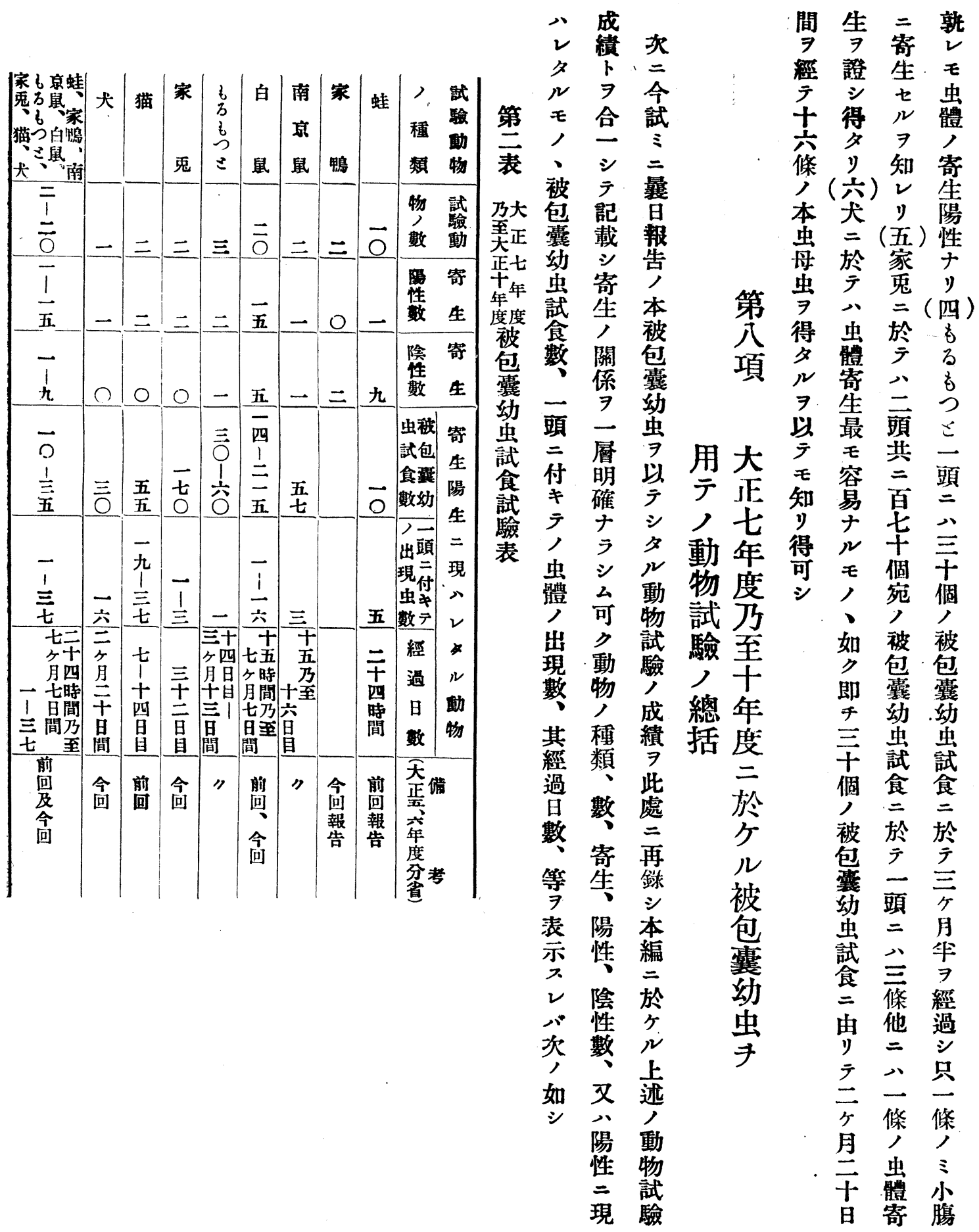


誌 內

二 驗 = 或

一 $\Rightarrow$ 經 種

八報嵒粗

七告的大

大 $七$ 奇

正榇生

九 $工$ 取虫

年卜

七 $丁$ 於

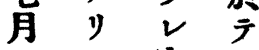

故重寄

故東生宗

本醫本七

虫事能

二新 $\exists$ 被

於誌全萄

モ 三

亦六得虫虫

斯文可時

正学,

性杂近

質年洊学

人泩

存自自

否七幼

知永出虫

今虫、發

三所笲

卜關大七

シ $シ$ N

次 公時

人近䅨二

實 藤 厂 於

驗 氏肺贸

$\exists$ 占毛

行報卞亦

り告气其

y幼 部

軎

東 三 終

京 關 末

醫 シ 宿

事テ表

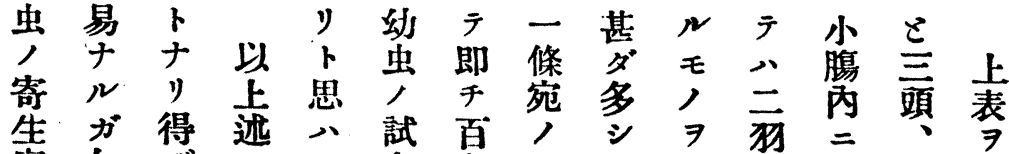

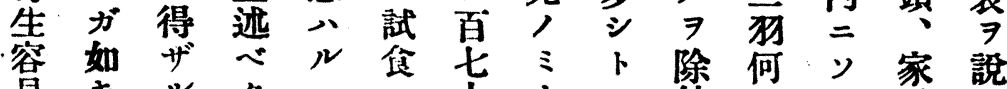

易 $₹ v$ \&

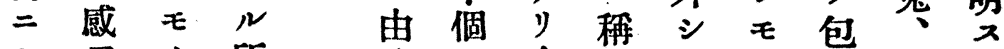

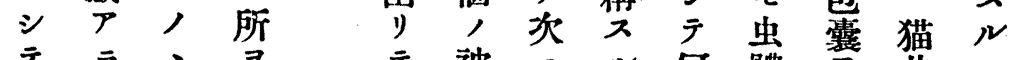

广

第县 $シ$ 如總容色家 $7 v$ 等脫三本

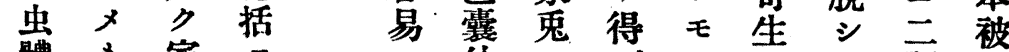
體 $を$ 家 $ス \quad$ 幼

發当鴊

老方如本

篮 $\varepsilon \neq$ 被

本士家鳥包

本・少鬼類 囊

幼 = 幼

於广虫

广 ,

八其 試

其 寄 食

寄 生 試

生 7 噞

率 證 =

極入於

動

物 小得少

試 ナ ズ 如

食然京冷

試

驗

二

就

テ

ト鼠血

白 物

犬鼠在

猫 如

, $\neq$ 厂

如 八,

₹ 稍一

哺本 時

孚虫.

動, 等

物 寄 生

$=$ 生 $=$

於 三

天向 天

空橆

本容 虫

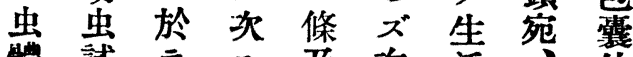

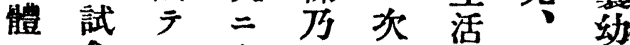

寄食赤方至南艺虫

生由方共京頭用

シ 頭つ條鼠體三七

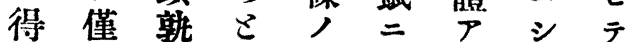

分 $v=$ 虫於り示行

, 一 二在體㘳夕、合

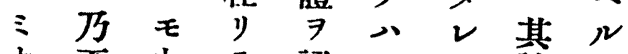

$ナ$ 至虫厂認三た陚陚

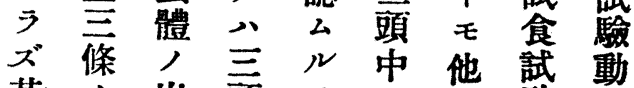

其, 出頭 7 - 分噞物

奇虫現中得頭時人 八

生體学三多落成蛙

數 7 頭》奇, 績云

赤認占 踓然生經

極ルモ天ド性浻㨜

x = 試虫 $モ \exists$ 共

变過食體試示三蛙至

多ギ被宾七虫公弱

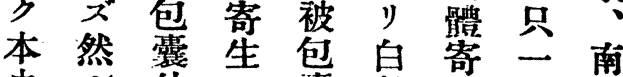

虫 $\nu$ 泑 $\exists$ 露鼠生頭京

察見幼点存三鼠

奇猫數名虫示在人文

宿”比 $ト ゙$ 此頭認試

主犬

$卜$ 的其五五後鼠

シ 於 極數 其頭 7 留

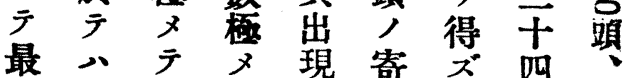

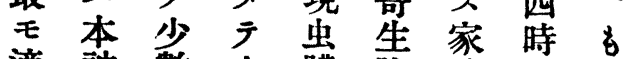

適被數少體蔭鴨間方

合包兰多數性 $=$ 後 


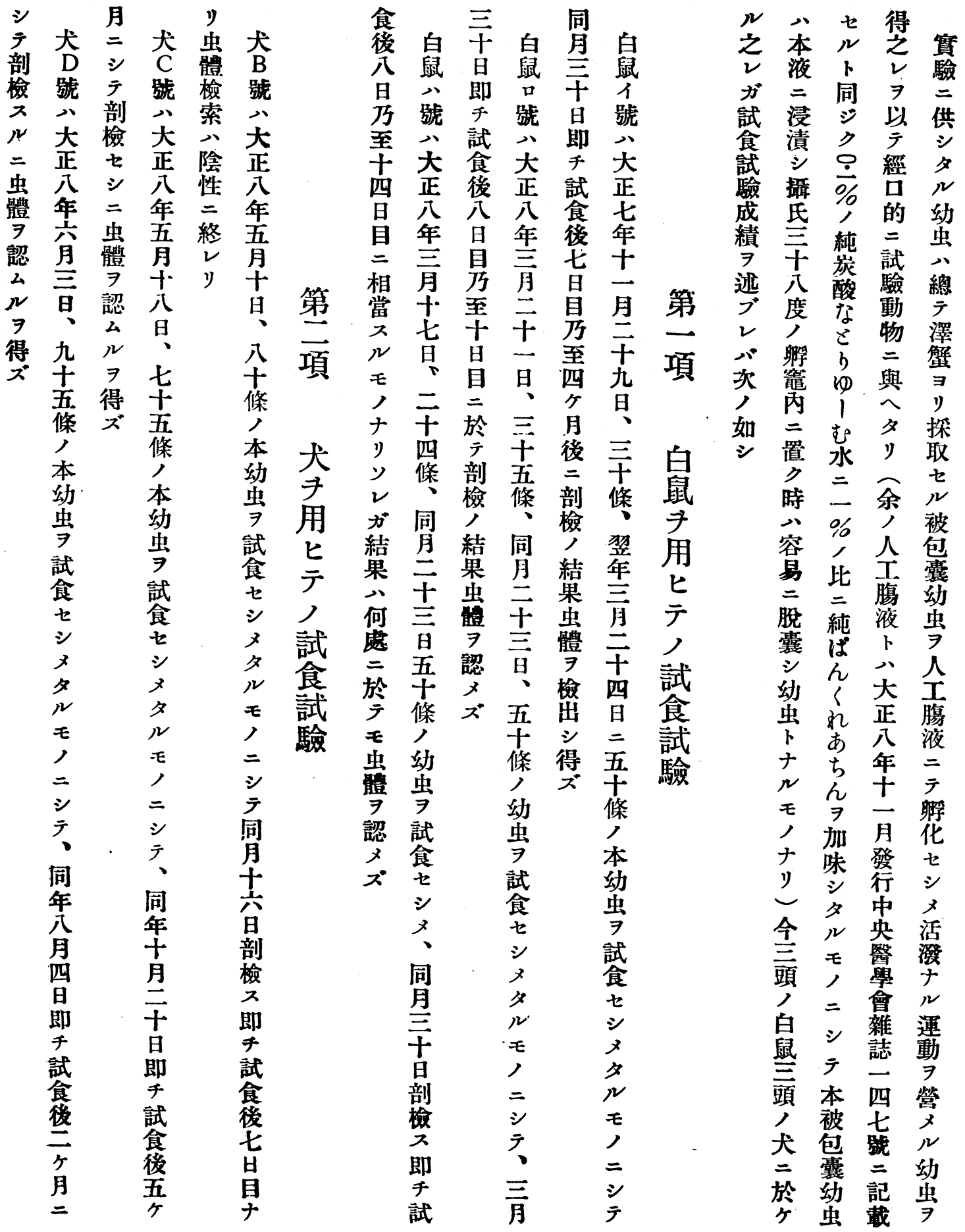




述 亮
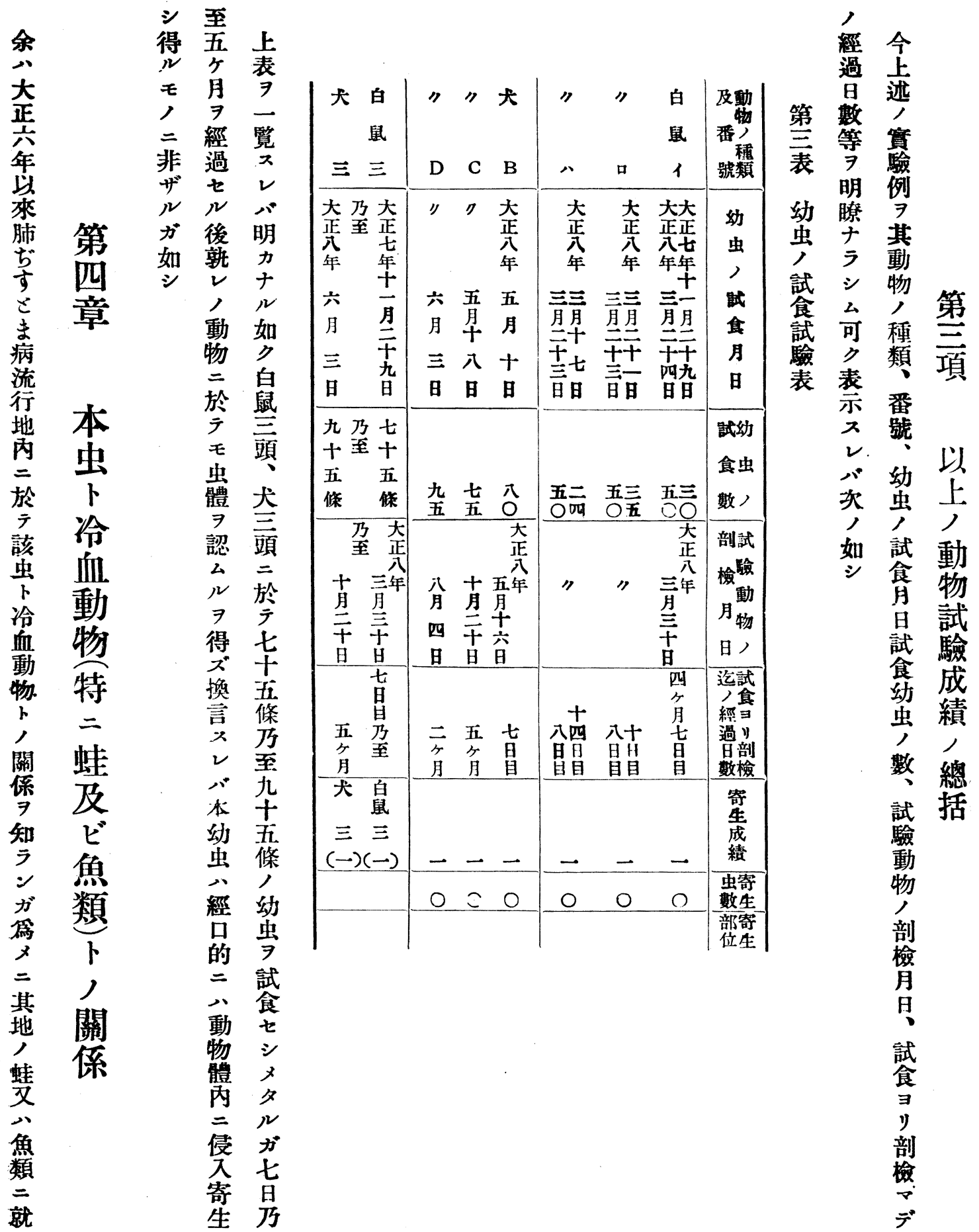
第虫本 試余本物人 分體七

二 寄虫 食第虫

例生厂試 一 齐

如第 驗

藤 $\rightarrow$ 流行本

某疑行视虫答

九 地 7 生

歳 E 唐 宁宿 シ

ノノ澤

女文两

、依 畔

大 正二八項 解息 ル

北三少貝决息先

年 三 數

旨兒人本

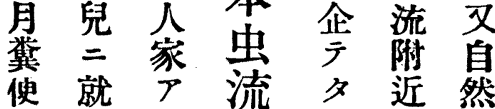

使就 $户$ 流夕近

檢 , 此行

检 地 地

多查,

數 成子人

人績 供

䖵戗 等

虫迎八番

卯 ブ 好 便

認 $ン$ デ檢

認 次 該 查

几人澤

二 如 蟹

キ

本七 得
第

於 二 久

於人 體

ル 鲜

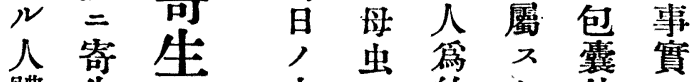

體生光中卢的卜幼永

スノ間ナ三踓虫河

粪 吸宿少蛙毛点流

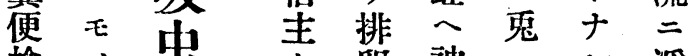

检, 出卡卿被三レ浮

查ナナシ

ニリリ $リ$ 企囊 蛙 モ

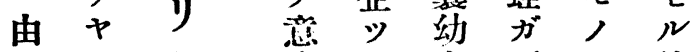

” 7 味

第知 $>カ ゙ \ni$ 然蟹虫

ス

故

此

等

小

兒

$=$

本
二

八甚

如試自, ,

可 $\neq$ 食然損 ち

キ事七二鹪充

$\Rightarrow$ 無 シ 本文る

述 $\neq$ 厶虫

ブ $ヨ ル ニ$ 死

ルリ 時 關 隇 お

二 観 二 係 $七$ カ

止察於 $几$ 蛙

虫 問

テ リ

人故
題
メステルト腸

ン 八コ同丙

卜 心 短 ト 時二

ス本時 $ノ=$ 攝

動 日儿蟹取
排前 丙需

囊內 $\neq$ 蛙 检

心二事及索

著 認 實 ビ

明 $\neg$ 魚怠

二ル發類 ラ

シ 被自 $习$ サ

テ包 ス捕

其 囊 $ル$ 獲

包幼之

囊 虫 得 声

モ

亦同 然 $三$ 同

元成 形 テ 時

七態大㒕余

少腸

壬 正管 此

, 年及新

ヒビ 吸

得月 其虫

夕十离二

リ日 容於

其 第 $\Rightarrow$ 天

大 一 細 モ

サ 流 檢 洂

直行七此

徑地り點

唐而二

三澤川 注

粍 $\exists$ 意

口捕 類 排

吸 獲 $=$

盤 七在 夕

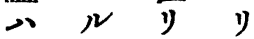

廣一于 助

徑 小 チ

官蛙 今

粍小迄告

腹 何 第

短芮等

德 二本乃

号於 吸至

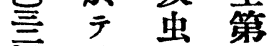

粍普年四

$>$ 通 關 流 


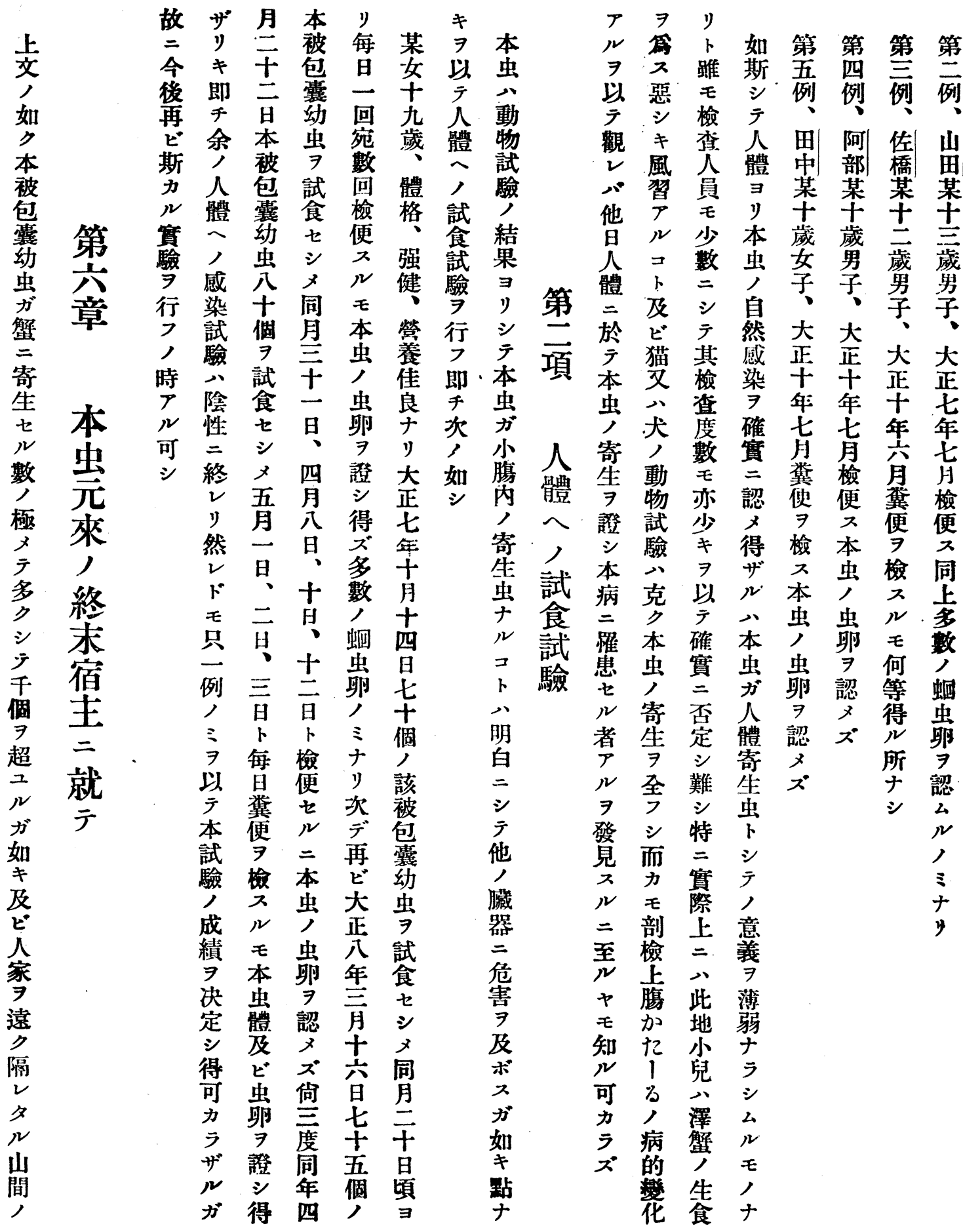




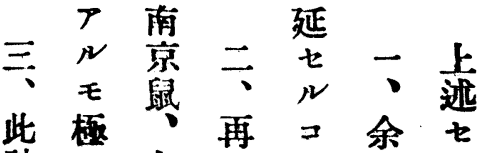

被白ビ卜京 包厅鼠種

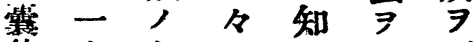
幼少如, 蟲部キ動り間二 分鼠物 宿 總

人 $=$ 簇

工過二本

腸 ギ 被

液ザリ包

$\exists ル テ$ 覇

以 $モ$ 小幼

$\bar{\gamma}$ 比虫

躬然 較

化 如 的試

七刀寄 食

圣生七

× 容 シ

夕猫易

$\nu=t$ \&

幼於 $v$,

蟲 テ ガ 成

八 如 績

之蛅 齐 $尹$

$\exists$ 蹬 然 通

經 $ン$ 覽

口寄 $ト$

的生 $モ N$

二容 $\delta=$

動易る鳥

物 = 類

白方 そ

鼠其家 鴨

出鬼

犬現 $=\overline{\bar{⿲}}$

$=$ $、 \bar{F}$

與 極 寄

ᄀ又生 其

ル テ 寄

モ多全生

寄

生 $几$ 的

證
圭括

七章

述

新 ブ

吸 2

虫

今次本

被如編

囊

幼

虫

余

研

究

地

$=$

於

广

芩

基

布

區

域

沉

$=$

シ

テ

县

$\bar{x}$

濃

厚

$=$
₹ 八 $ノ$ 二容流 $ノ$ 溪

，鼠 八如雨於物行沿歸流

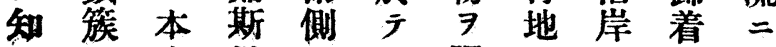

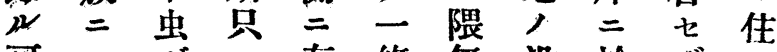
可八唯三存條無沿於ザ七

$\neq$ 體自例在, $\Rightarrow$ 岸方次 ナ格然而 $三$ 吸检, 何蟹 y, $=$ 力余虫甞俵鼠力三 矮少 $モ>\exists$ 家 $\exists$ 於 小ク幼新檢り, 捕 ズ ナ 卜 虫吸出然各獾而 $モ$

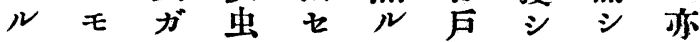

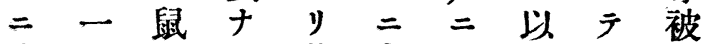
比定 $=ル$ 其大捕示最色 時自 $コ$ 大正鼠之モ囊 旦然卜节干器其幼

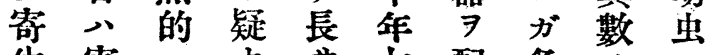
生寄二十贲七配各少, 容生宿的品置蔵多寄

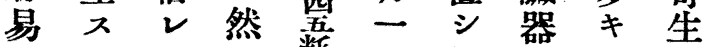
$=ル ル レ$ 粍捕 $\ni$ 八荤 シ $モ$ ト 收

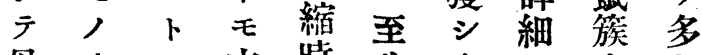
母大ヨ本時当夕二ナ寻 虫 $\nu 川$ 虫 $=$ 安 $\nu$ 检 $\nu$ 點 二八シ $心$ 品鼠索可 $\exists$ 發明亏 未号某心湆

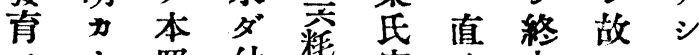
入十吸幼粍笔手

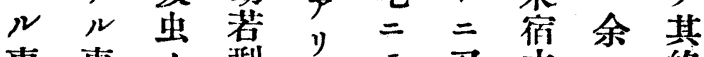
事事了型幅示又主公終

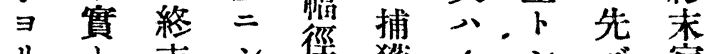
》贞禾 考十宿 テ吕七括厅此主

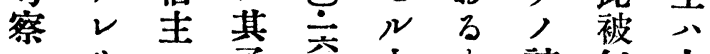
ス”父莪中ま該包人

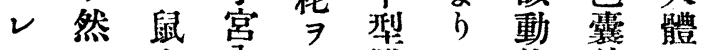
バナ丙有雌几物幼二 鼠 $F y=$ 入

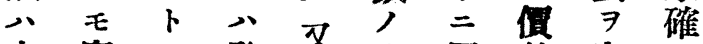

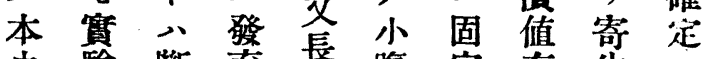

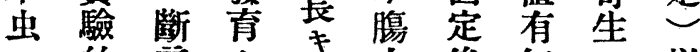
二的言 $七$ 維 後

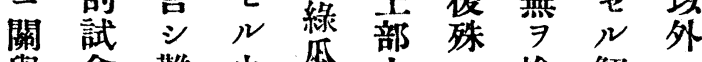
興食難虫瓜士三检蟹二

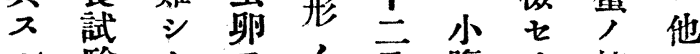

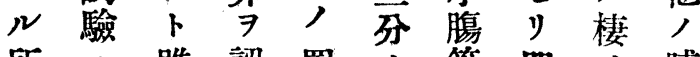
所三踓認睪, 管 即多哺

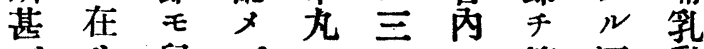

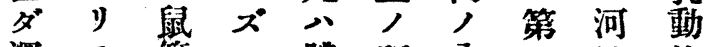
梁 栄體所內一流物 
雜

雑

同一同同年行安

四吉上㫐地 藤

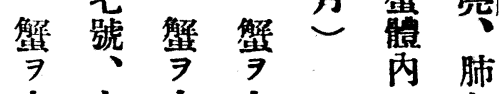

中大中中 $中$ 占

間 正間間存番

宿八宿宿 スこ

圭年主主、肺ま

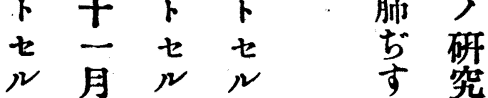

余余紊新学第

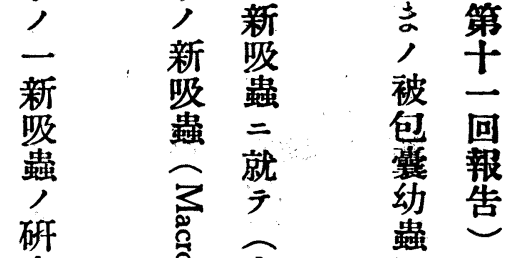

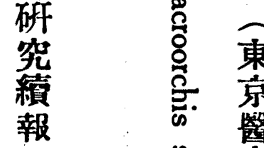

日

早

病

理

理 $\div$ 亲

學宛杂被

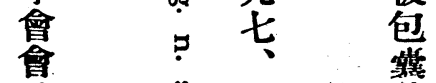

誌串八

第

年研夲就

大 筧正 テ

正 第年 中

年高公鸯

士 㙰 學

司 告 $\quad$ 會

$\begin{array}{ll}\text { 中 } & \text { 誌 } \\ \text { 央 } & \text { 㗨 } \\ \text { 㓱 } & \text { 鿖 }\end{array}$

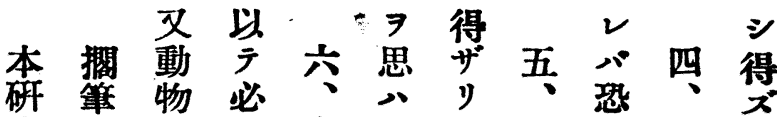

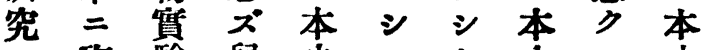

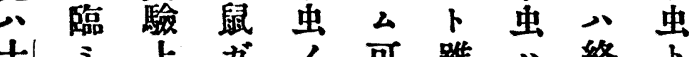

士藤上古自流踓心終贞

氏浪容然行 中體宿 血

獎 教 易二地 間 二主動

學授二本域宿等卜物

資並鼠虫主生 シ

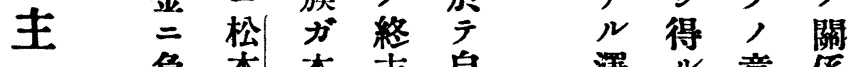

要負本本柰息 澤意俰

要 $\mathrm{y}$ 教虫宿然蟹義 $尹$

所授”主

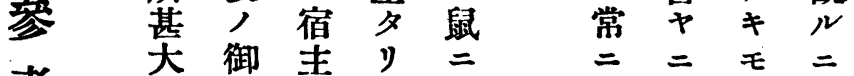

考大留多得本好就, 殊

書 リ第りル虫 ミテト

茲大得卜广文只踓蛙

日 $=N ル$. 寄攝人民二

謹御 コ㙄生取工中於

三指卜言 $尹$. 又的間 $\bar{~}$

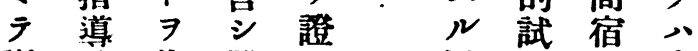

謝及此難滛食毛

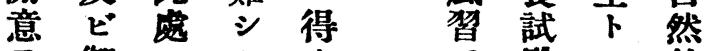

$\exists$ 御 $=1$ \% 驗 $三$ 的

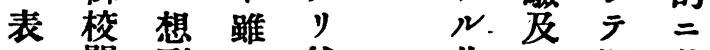

ス閱 到モ 然此 ビ關 其

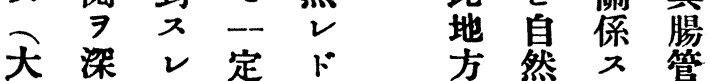

正謝 $八$ 時 $E$ 的 $N$ 內

十 万本目此於二所

年虫間者夏人被

八

月關本虫體 $\exists$ 可囊

八 係虫三寄り

日 $九$ 需迄生虫蟲

脫 $心$ 生發 等體

稿所三亩 證文檢

少關を゙ オ 品出

ラ 與ザル 摡光

ザル シ 日, 只

$N=$ 或排卜

可占ノ 分出学

卜白り 少確考

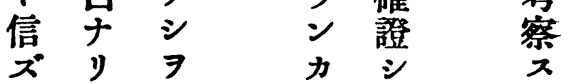




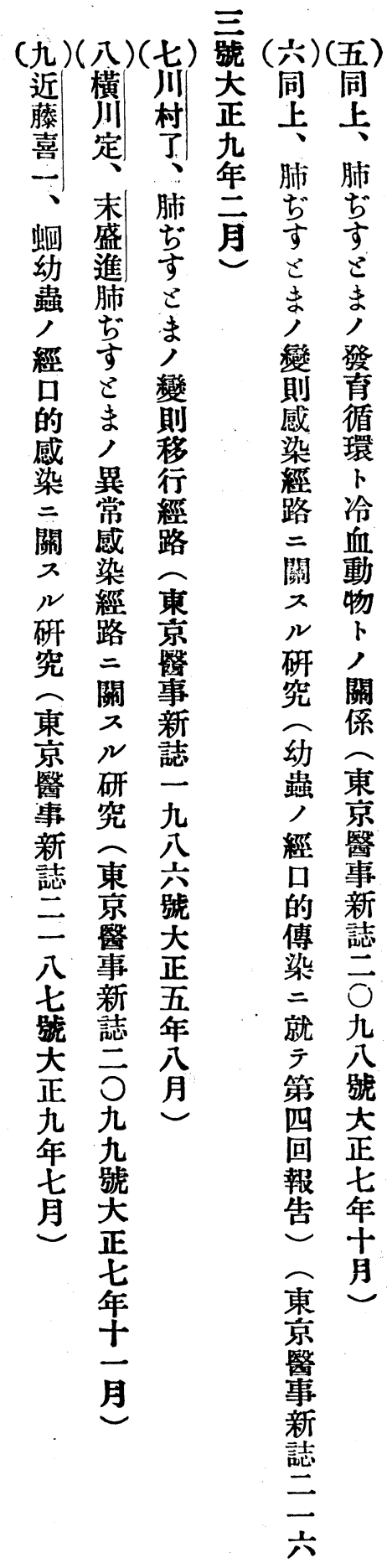

